Mesozoic Era is fully discussed in terms of oceanic distribution and low albedo leading to peak temperatures in midCretaceous time (say $100 \mathrm{Myr}$ ), since when a fluctuating decline ensued.

Frakes' work is scholarly; not every point of opinion is referenced; this may irritate some, but too frequent a punctuation with brackets would have been more irritating. There is, however, an adequate supply of references in the text to most data to be used, with a list at the end of about

\section{Primordial germ cells}

\section{C.C. Wylie}

Primordial Germ Cells in the Chordates. By P.D. Nieuwkoop and L.A. Sutasurya. Pp.187. (Cambridge University Press: Cambridge, 1979.) £14.50.

THE establishment of the gonad in early vertebrate embryos has fascinated developmental biologists and cell biologists for well over a century now. Basically, the problems fall into the following categories: (1) how is the germ line determined in the early embryo?; (2) what is the mechanism by which the primordial germ cells (PGCs) migrate from the site of their determination to the site of gonad formation?; and (3) what is the mechanism by which PGCs are guided to their target? Thus, many of the cellular processes which make development such a fascinating process are encapsulated in this
500 to 600 works and an adequate index. This book establishes palaeoclimatology as an inseparable part of stratigraphy, itself the documentary basis for understanding most aspects of Earth history.

W.B. Harland is Reader in Tectonic Geology at the University of Cambridge. He is currently leading the International Geological Correlation Programme Project No. 38 on PrePleistocene Tillites.

particular piece of organogenesis, and this has been reflected in the considerable research interest in this subject.

It is therefore timely that Professor P.D. Nieuwkoop's book about the PGCs of the chordates has appeared, for this is a thorough and clear survey of work in this field over the past hundred years. However, despite the authors' considerable contribution to the field, and some five hundred cited pieces of work, we are still only able to answer the above three fundamental questions in the most general way.

Professor Nieuwkoop's main contribution, and indeed, the main preoccupation in his book, is the site and manner of determination of the first germ line cells (the "presumptive" PGCs). The fact that these seem to differ in two vertebrate groups which have been closely studied, the anuran and urodele amphibians, leads him to speculate that the evolutionary tree of the vertebrates, particularly with respect to the amphibians, may be more complex than has been hitherto suspected.

The study of taxonomy through careful study of ontogeny has a long and honourable history, and has tended to be neglected of late. This is largely due to a focussing of research interest on to the cellular and molecular events of embryogenesis, in an attempt to define causative factors in cell differentiation. It is therefore a timely reminder by the author that molecular and cellular phenomena of development are just as important clues in taxonomy as are anatomical features.

This concentration on the taxonomic aspects of the PGCs in chordates is both a strength and a weakness. The weakness is simply because the data on the establishment of the germ line cells, and the route they take to the developing gonad, are still only documented in a fragmentary and unsystematic way. The middle section of the book contains a truly excellent description of this. However, when examined critically, hard evidence on the means by which the germ line is established in chordates only exists for a small number of amphibian species, and not at all for the amniotes, making this a rather tenuous reason for tinkering with the chordate evolutionary tree. The strength of this approach, however, is that it is bound to stimulate research in this subject, particularly into those groups which so far have been neglected. This, in turn, will fulfil Professor Nieuwkoop's aim to gain insight into the way in which the causative factors in early development have themselves changed during vertebrate evolution.

C.C. Wylie is Senior Lecturer in Structural Biology at St George's Hospital Medical School, London, UK.

\section{Plasma proteins}

\section{M.J. Geisow}

Plasma Proteins. Edited by B. Blomback and L. Hanson. Pp. 401. (Wiley: Chichester, UK, and New York, 1979.) £22.50.

SwEDISH readers will already know about this book because it first appeared in Swedish in 1976. The latest edition of this multi-author volume is a revised version in English and now includes some literature references up to 1978 . The promotors are KABI AB, the Swedish firm which supplies plasma protein fractions.

Plasma Proteins is described as an educational text and a clinical handbook. This seems to be a fair description. The introductory chapter by Kai Pedersen is a small nugget of biochemical history. Apart from exposing the roots of plasma protein science, it also deservedly, but not selfishly, establishes the Swedish contribution to the field. The remaining chapters form a comprehensive account of the biochemistry, pathology and methodology of plasma proteins. The treatment of this material is similar to that in the more expansive work The Plasma Proteins (F.W. Putnam, ed., Academic: New York; 1975). In contrast with the latter work, however, you might consider reading the KABI book from cover to cover.

Inevitably for a textbook produced several years ago, there are omissions. For instance, the recent considerable advances in the three-dimensional structure of lipoprotein have not been incorporated in the otherwise excellent description. Nevertheless, as an educational text, the chapters are informative and easy to read. Despite multi-authorship, the closelylinked subjects of defence and repair (that is, the antibody/lymphocyte and blood clotting systems) are treated in a unified fashion.

At a molecular level, there is a pleasing emphasis in this book on the structures of plasma proteins. For example, there are good descriptions of the functions of the transport proteins albumin and haptoglobin in relation to what is known about their molecular structures. A similar molecular structure/biological function synthesis is achieved in the chapters on the protective proteins fibrinogen and plasminogen.

The bench worker is catered for by the thoughtful inclusion of much useful physical and chemical data relating to the individual proteins described. Both historical and current purification techniques are given and there is a discussion of industrial methods for the fractionation of plasma.

At a more clinical level, hospital biochemists have been given a generous amount of space in which normal and pathological states of plasma protein chemistry is covered. There are short but clear descriptions of the main diagnostic plasma protein analytical techniques, with electrophoretic separations in full colour.

I expect to see this book above the benches in the teaching hospitals - both in the pathology labs and in the medical schools.

M.J. Geisow is a member of the research staff at the National Institute for Medical Research, London, UK. 